\title{
Halal Industry in Indonesia; Challenges and Opportunities
}

\author{
Ferry Khusnul Mubarok, Muhammad Khoirul Imam \\ Fakultas Ekonomi dan Bisnis Islam, Universitas Islam Negeri Walisongo Semarang
}

\section{A R T I C L E I N F O}

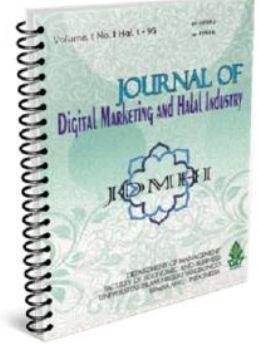

Article history:

Received 22 June 2020

Accepted 03 July 2020

Published 10 July 2020

Keywords:

Halal Industry, Strategy, SWOT

Analysis.

\begin{abstract}
A B S T R A C T
The global halal industry has shown significant development, and Indonesia has become one of the countries with great potential. This study aims to identify opportunities and challenges in developing the halal industry in Indonesia. This research uses a qualitative approach. Data sources used in the form of secondary data, which comes from library sources-technical analysis of data using the SWOT analysis approach. The results showed that the development of the halal industry in Indonesia included several sectors, namely the food and beverage sector, tourism, fashion, media and recreation, pharmaceuticals and cosmetics, and renewable energy. Based on SWOT analysis, it was found that there are strengths, weaknesses, opportunities, and challenges in developing the halal industry in Indonesia. Thus, in the future, to improve the halal industry in Indonesia, it is necessary to optimize the synergy of various elements ranging from the community, industry players, government, financial institutions, associations, academics, and educational institutions, as well as other related parties.
\end{abstract}

@2020 Journal of Digital Marketing and Halal Industry

\section{Introduction}

The development of the global halal industry experienced significant development (Hamid et al., 2019). This development does not only refer to countries with a Muslim majority but also minority countries (Adha et al., 2017; Haryani et al., 2017). Halal labelling is a global concern, especially for product quality assurance and living standards (Anggara, 2017; Pratisti \& Maryati, 2019). Muslims choose the guarantee of halal products and services as a form of adherence to religion, while for nonMuslims, the reasons are in the form of guarantees of cleanliness, safety, quality carried out from the beginning to the end (Nurrachmi, 2018). Various sectors that are developing rapidly in the halal industry include the food sector, finance, travel,

\footnotetext{
* Corresponding author. email: ferrykhusnulmubarok@walisongo.ac.id DOI: http://dx.doi.org/10.21580/jdmhi.2020.2.1.5283
} 
fashion, cosmetics and medicine, media and entertainment, healthcare, and education ( $\mathrm{Ab}$ Talib \& Hamid, 2014).

The tendency to choose an Islamic lifestyle is still growing (Tieman \& Darun, 2015). This growing trend is not only related to Muslim consumers choosing food products that are following Islamic demands, namely meat, milk, and other processed products. Now it has grown for clothing, cosmetics, real estate, restaurants, hotels, Islamic banking, then to an integrated Islamic school (Johan, 2018). The high growth of Islam in the world of Indonesia and its young adherents, as well as the increasing purchasing power of young Muslim consumers, has become a new wave affecting the business world (Tri Ratnasari et al., 2019). The State of the Global Islamic Economy report ranks Indonesia first for halal food product consumers, which is $\$ 154.9$ billion (State of The Global Islamic Economy: 2018). However, the Indonesian government has not been able to maximize the market potential because Indonesia is still ranked 10th in the category of halal food producers.
Indonesia is a country that has the largest Muslim population in the world (Norafni Farlina et al., 2013). Based on data from The Pew Forum on Religion \& Public Life, the number of Indonesians who are Muslim is 209.1 million people or 87.2 percent of the total population of Indonesia. That number represents $13.1 \%$ of all Muslims in the world. While globally, the entire Muslim population of the world will increase from 1.6 billion people in 2010 to 2.2 billion people in 2030 . Indonesia, which is the country with the largest Muslim population in the world, spent the U.S. \$ 218.8 billion for the Islamic economic sector in 2017. Therefore, Indonesia has the potential to become the country with the most extensive halal product in the world. But Indonesia has not been able to maximize the market potential. This is evident from Indonesia, and It appears that Indonesia has not been ranked in the top 10 for the category of halal food producers in the State of The Global Islamic Economy (2018).

Table 1. Indonesia's Position in the Development of Halal Industry

\begin{tabular}{lllllll}
\hline No. & Halal Food & $\begin{array}{c}\text { Islamic } \\
\text { Finance }\end{array}$ & Halal Travel & $\begin{array}{c}\text { Fashion } \\
\text { Model }\end{array}$ & $\begin{array}{c}\text { Halal Media and } \\
\text { Recreation }\end{array}$ & $\begin{array}{c}\text { Pharmacy and } \\
\text { Halal Cosmetics }\end{array}$ \\
\hline 1 & UAE & Malaysia & UAE & UAE & UAE & UAE \\
2 & Malaysia & Bahrain & Malaysia & Indonesia & Singapura & Malaysia \\
3 & Brazil & UAE & Turki & Singapura & Qatar & Singapura \\
4 & Oman & Saudia & Indonesia & Malaysia & Malaysia & Jordan \\
5 & Jordan & Kuwait & Maldives & Tukey & Lebanon & Pakistan \\
6 & Australia & Qatar & Thailand & China & Bahrain & Brunei \\
7 & Brunei & Pakistan & Tunisia & Italy & United Kingdom & Egypt \\
8 & Pakistan & Oman & Azerbaijan & France & Germany & Saudi Arabi \\
9 & Sudan & Jordan & Jordan & Bangladesh & France & Bahrain \\
10 & Qatar & Indonesia & Albania & Srilanka & Brunei & Azerbaijan \\
\hline
\end{tabular}

Source: The State Global Islamic Economic Report 2018/2019 
Research on the halal industry has been widely carried out; a study from Ismoyowati (2015) states that one of the factors influencing people's consumption behaviour is halal aspects. Thus, the halal element becomes an essential part of the development of the industry going forward. Waharini \& Purwantini (2018) concludes that the halal food industry in Indonesia has enormous potential, and even ranks first as a halal food consumer in the world. The research of Mei et al., (2017) states that halal food supply chains ranging from raw materials to ready-to-eat ingredients or starting from the agricultural process to how to cook them, to ensure that halal integrity is needed. Besides that, to be a leading sector of the halal industry, Indonesia must have a security system in the halal food trade route, the system is commonly known as Security Strategies and Non-Tariff Barriers (NTBs) (Ratanamaneichat \& Rakkarn, 2013). This study aims to identify the development of the halal industry in Indonesia, identify the strengths, weaknesses, opportunities, and challenges of the halal industry in Indonesia, and identify strategies for developing the halal industry in Indonesia.

\section{Literature Review}

The concept of halal in basically is not only related to food and drink but more than that, the idea of halal-haram applies in various aspects (Haleem, 2017). Halal-haram deals with the law on a matter, whether something is permissible or not, prohibited or not prohibited. In Islam, the halal-haram provisions are expressly conveyed, both through the Qur'an and Al-Hadith. In the Qur'an, the verses that mention the word halal are not small, for example, in the Q.S. Al-
Baqarah verses 168, 172, 187, 275; Q.S. Ali Imran verses 50, 93; Q.S. An-Nisa verse 160; Q.S. Al-Maidah verses 1, 4, 5, 87, 88, Q.S. AnNahl verses 66-69, 114-115; Q.S. Thaha, verse 81; Q.S. Al-Hajj verses 27-28; Q.S. AlMukminun, verse 51; Q.S. Yasin verses 33-35, 71-73, Q.S. Al-A'raf, verse 157, etc.

Based on these verses, the definition of halal and haram is apparent, where everything good (body, mind, and soul) is lawful, whereas everything that brings danger (body, reason, and soul), then the law is haram (Omar et al., 2012). Halal-haram for Muslims, this relates to how the impact on life today and also life after death (Anismar et al., 2018). In other words, for halal-haram Muslims is related to maintaining health and maintaining obedience. Meanwhile, for non-Muslim, halalharam is only related to how aspects of life in this world are fulfilled, without regard to how it will be in life after death (Park \& Jamaludin, 2018).

Halal and haram in various matters are related to whether or not something is prohibited (AlKwifi et al., 2019). Thus the halal industry is an activity to process or process goods or objects by Islamic regulations (Baharuddin \& Kassim, 2015). The purpose of the halal industry, according to Law No. 33 of 2014 concerning Guaranteed Halal Products, is that the State must provide protection and guarantees about the halal status of a product. Article 1 of the Law, referred to as halal products, includes "goods and or services related to food, beverages, medicines, cosmetics, chemical products, biological products, genetic engineering products, as well as used goods that are used, applied or utilized by the community. "Meanwhile, according to the State of the Global Islamic Economy (2018), there are six sectors in the Halal 
industry, including "food and beverages, clothing, halal tourism, entertainment and media, pharmaceuticals and cosmetics. In the future, we need a precise definition, where the halal industry is not only limited to halal products, but also lifestyle. Based on the report of the Ministry of National Development Planning (2019), the halal industry sector in Indonesia includes food and beverages, tourism, fashion, media and recreation, pharmaceuticals and cosmetics, renewable energy, and support of Islamic financial institutions.

\section{Research Method}

This study uses a qualitative approach, namely, by describing the development of the halal industry in Indonesia, starting from the strengths, weaknesses, opportunities, and challenges, as well as its development strategy. The data source used is secondary data. Data collection techniques using library search. Library search in the form of books, research, websites, and other relevant library sources. Data analysis techniques used a descriptive approach through the SWOT Analysis method.

\section{Result and Discussion}

Development of the Halal Industry in Indonesia

Indonesia is a country with the majority Muslim population in the world. This has become one of the strengths for Indonesia to become a leading global halal industry. Potential sectors to develop in Indonesia include food and beverages, tourism, fashion, media and recreation, pharmaceuticals and cosmetics, and Islamic finance.

The first sector is food and beverages. In this sector, especially in Indonesia is Indonesia's superiority, this is due to the dominance of the population, especially in areas that are predominantly Muslim. Various types of food and beverages typical in very diverse regions are also a separate opportunity for Indonesia. Based on data from the Central Statistics Agency (BPS), the food and beverage industry is one sector that has a significant contribution to the processing industry sector. This can be seen in the contribution of this sector to the Gross Domestic Product. In addition, halal-certified products in Indonesia have also increased.

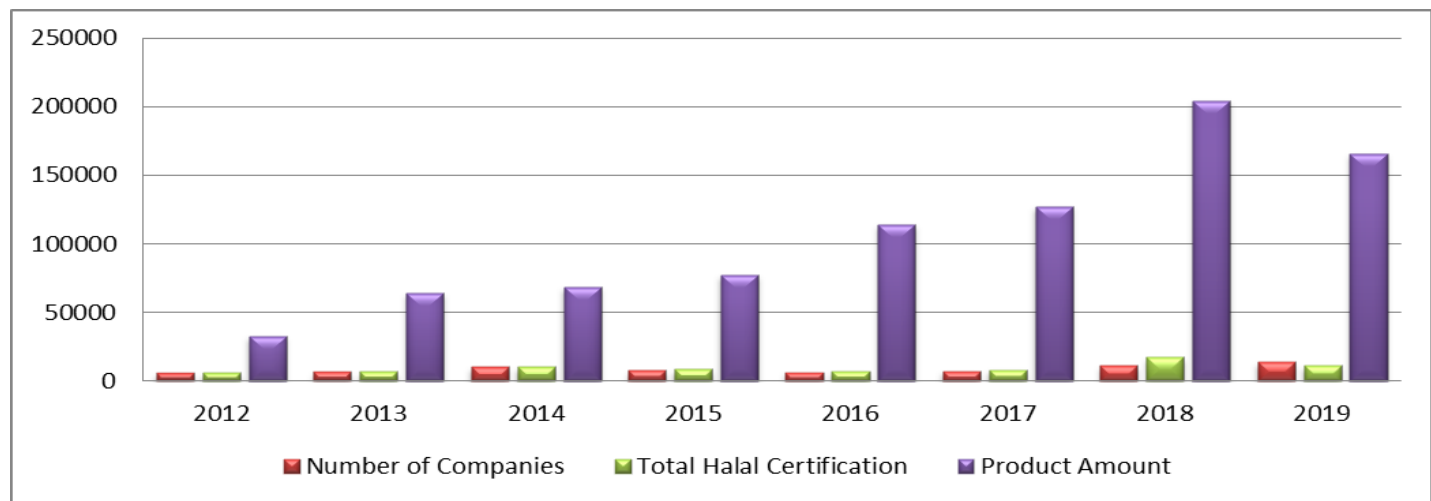

Source: LPPOM-MUI processed

Figure 1. Development of a halal-certified company 
The second sector is tourism. In Indonesia, tourist destinations are also available quite a lot with various choices. This is because Indonesia is a country that has 17,508 islands, so it has a variety of potential tourist attractions. Attractions both on land and in the sea are not few, besides that the appeal of Indonesia also refers to the richness of local culture. Besides general tourist destinations, religious-based tourism is also quite developed; for example, walisongo pilgrimage, mosque tours, and various other halal tourism areas. To support this sector, it is necessary to have good transportation facilities (air, sea and land), hotels and accommodations, restaurants and cafes, as well as travel and tours.

The third sector is fashion. The development of the fashion industry in Indonesia began in 2010 and continues to grow until now. This is indicated by the high market demand, so that it raises various things such as designers, exhibition events, to events with the theme of Islamic fashion. In the global sphere, Indonesia is even ranked 2 nd in the top 10 indicators of the Muslim fashion sector.

The fourth sector is the media and recreation, and the sector is currently one of the creative economy subsectors that have potential. The growth of film, animation, and video has increased significantly. This increase was also one of them as a result of the existence of the Covid-19 pandemic. However, in the context of halal-based media and recreation is not yet optimal; this is indicated by the lack of public interest in religious-based films.

The fifth sector is pharmaceuticals and cosmetics. In this sector is a sector that has good potential. This is because pharmaceuticals and cosmetics become one of the fundamental needs in the current era. Indonesia based on the State of Global Islamic
Report in 2018, became the 4th largest country as the country with the highest consumption of pharmaceutical products. From the cosmetics sector, Indonesia is the second country with the largest amount of cosmetics consumption after India. The consumption trends of these two things continue to increase from year to year.

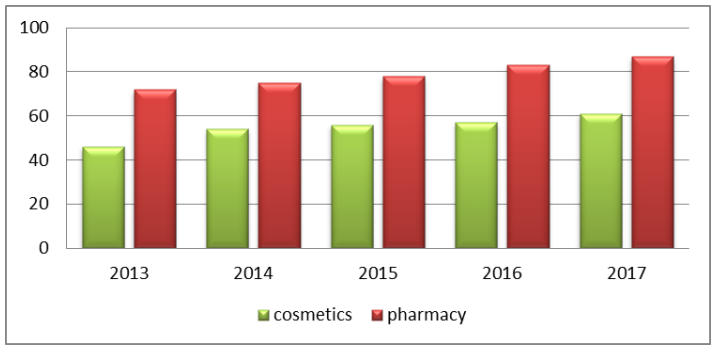

Source: Global Islamic Economy Report (2018) processed

Figure 2. Global Muslim Consumption of Pharmacy and Cosmetics in U \$ D

The last sector is the Islamic financial sector. This sector is one of the determining factors in the smooth running of funding and capital, especially for halal industry players. This is because to be able to develop the halal industry sector requires funding or financing that is easy and inexpensive, and also requires effective and efficient operations. The Islamic financial institutions that can be developed and are expected to be able to contribute to the progress of the halal industry in Indonesia, including Sharia Banking, Islamic Capital Markets, Sharia Non-Bank Financial Institutions, Philanthropic Institutions, and other financial institutions.

\section{SWOT Analysis of the Halal Industry in Indonesia}

The development of the halal industry in Indonesia is quite significant. However, the 
right strategy is needed to develop the industry. So that Indonesia's opportunity to become a leading sector in the global halal industry can be realized. To achieve this, identification needs to be started from strengths, weaknesses, opportunities and challenges so that the strategies implemented are able to run optimally. The SWOT analysis of the halal industry in Indonesia can be seen in table 2.

\section{Table 2. SWOT Analysis of the Halal Industry in Indonesia}

\begin{tabular}{|c|c|}
\hline Strenght & Weakness \\
\hline $\begin{array}{l}\text { - } \text { Government support in the halal industry } \\
\text { - The existence of a certification body that } \\
\text { - Sas survived } \\
\text { - Significant halal product campaigns } \\
\text { not only Muslims but also non-Muslims } \\
\text { especially in the food and beverage sector } \\
\text { - Various institutions and institutions of } \\
\text { higher education have the potential to } \\
\text { become centres of innovation } \\
\text { - Sharia economic and financial } \\
\text { developments }\end{array}$ & $\begin{array}{l}\text { - The low awareness of industry players and } \\
\text { the public about the importance of halal } \\
\text { aspects. } \\
\text { - The lack of cooperation between the same } \\
\text { industry sector. } \\
\text { - Policy framework and product guarantee } \\
\text { protection that are not yet established } \\
\text { - Lack of halal-certified companies }\end{array}$ \\
\hline Opportunities & Treatment \\
\hline $\begin{array}{l}\text { - The largest Muslim population in the world } \\
\text { - Increased demand for halal products and } \\
\text { - } \text { services } \\
\text { - } \text { ASEAN Free Trade Area (AFTA) } \\
\text { - The use of IT in online trading } \\
\text { - Investment opportunities in halal-certified } \\
\text { industries } \\
\text { - Various research studies that lead to the use } \\
\text { of halal products }\end{array}$ & $\begin{array}{l}\text { - Various countries, both Muslim and non- } \\
\text { - Muslim, develop the halal industry } \\
\text { - Product quality that does not yet have } \\
\text { competitiveness } \\
\text { - The rampant non-halal products and the } \\
\text { circulation of non-halal materials } \\
\text { - Low awareness about the use of non-halal } \\
\text { materials, especially for small scale } \\
\text { producers } \\
\text { - There is no uniform halal standardization } \\
\text { - SARA issues are still quite strong }\end{array}$ \\
\hline
\end{tabular}

Development Strategy for Halal Industry in Indonesia

Based on a SWOT analysis of the halal industry in Indonesia, the strategy to optimize the halal industry in Indonesia is to strengthen various sectors and also improve the synergy of all elements. The strategies that can be carried out include the following: 
a. Improve socialization and education about the importance of halal certification to the people of Indonesia and industry players, both small and large.

b. Strengthening legal certainty

c. The government needs to optimize plans and disseminate information on halal industrial areas to improve the quality of Indonesian halal products.

d. They are increasing the quality of Indonesian halal industry products in order to compete in the domestic and international markets.

\section{Conclusion}

Based on the results and discussion, it can be concluded that the development of the halal industry in Indonesia includes several sectors, namely the food and beverage sector, tourism, fashion, media and recreation, pharmacy and cosmetics, and Islamic finance. Based on SWOT analysis, it was found that there are strengths, weaknesses, opportunities, and challenges in the development of the halal industry in Indonesia. Development strategies focus on increasing the role of stakeholders and the community in developing the industry and optimizing policies by maximizing product quality.

\section{Recommendation}

Based on these results, in the future, it is necessary to have efforts to improve, including:

a. To the government to be more fully supportive especially related to various policies that can encourage this sector to grow and develop, which later Indonesia can become a leading sector in the halal industry.

b. To the actors in the halal industry sector, there needs to be synergy between industry players in this sector, so that the progress of this sector is motivated by the spirit of togetherness and mutual support between actors so that later they can compete on a global level.

c. To the public, to be able to pay more attention to the halal aspects of the various consumables carried out, and also provide constructive criticism and suggestions for stakeholders in this industry.

d. Subsequent research can identify in detail, by exploring in detail the halal industry stakeholders.

\section{References}

Ab Talib, M. S., \& Hamid, A. B. A. (2014). Halal logistics in Malaysia: A SWOT analysis. Journal of Islamic Marketing, 5(3), 322-343.

https://doi.org/10.1108/JIMA-03-20130018

Adha, N. ', Hamid, A., Shahwahid, F. M., Othman, N., \& Saidpudin, W. (2017). Challenges and Ways Improving Malaysia Halal Food Industry. Special Issue Sci.Int.(Lahore), 29(2), 149-153. http://www.sciint.com/pdf/636300567525518330.pdf

Al-Kwifi, O. S., Abu Farha, A., \& Ahmed, Z. U. (2019). Dynamics of Muslim consumers' behavior toward Halal products: Exploration study using fMRI technology. International Journal of Emerging Markets, 14(4), 689-708. https://doi.org/10.1108/IJOEM-11. 2017-0486 
Anggara, F. S. A. (2017). Development of Indonesia Halal Agroindustry Global Market in ASEAN: Strategic Assesment. Al Tijarah, 3(1), 82. https://doi.org/10.21111/tijarah.v3i1.9 40

Anismar, Satria, D., \& Ali, M. (2018). Religious Tourism: Concept of Community-Based TourisminAceh Singkil, Indonesia. Proceedings of MICoMS 2017, 1, 283-288. https://doi.org/10.1108/978-1-78756793-1-00086

Baharuddin, K., \& Kassim, N. A. (2015). Understanding the Halal Concept and the Importance of Information on Halal Food Business Needed by Potential Malaysian Entrepreneurs. International Journal of Academic Reserach in Business and Social Sciences, 5(2), 170-180. https://doi.org/10.6007/IJARBSS/v5i2/1476

Haleem, A. a. (2017). Towards successful adoption of halal logistics and its implications for the stakeholders. British Food Journal, 119.

Hamid, A., Said, M., \& Meiria, E. (2019). Potency and Prospect of Halal Market in Global Industry: An Empirical Analysis of Indonesia and United Kingdom. Business and Management Studies, 5(2), 54-63.

https://doi.org/10.11114/bms.v5i2.416 7

Haryani, D., Ag, D., \& Martin, D. (2017). Key Challenges and Issues Consumer Face in Consuming Halal Product. 7(11), 590-598. https://doi.org/10.6007/IJARBSS/v7i11/3498
Ismoyowati, D. (2015). Halal Food Marketing: A Case Study on Consumer Behavior of Chicken-based Processed Food Consumption in Central Part of Java, Indonesia. Agriculture and Agricultural Science Procedia, 3, 169-172. https://doi.org/10.1016/j.aaspro.2015.0 1.033

Johan, E. (2018). New Challenges in Asean Regional Market: International Trade Framework on Halal Standard. Jurnal Dinamika Hukum, 18(1), 93. https://doi.org/10.20884/1.jdh.2018.18 .1 .809

Mei, J., Mahmood, S., Joe, C., Regenstein, M., Soon, J. M., \& Regenstein, J. Mac. (2017). Halal integrity in the food supply chain. https://doi.org/10.1108/BFJ-042016-0150

Nasional, K. P. P. (2019). Masterplan Ekonomi Syariah Indonesia 2019-2024.

Nurrachmi, R. (2018). The Global Development of Halal Food Industry: A Survey. Tazkia Islamic Finance and Business Review, 11(1). https://doi.org/10.30993/tifbr.v11i1.11 3

Omar, S., Zahrain, M., \& Mohd, B. (2012). Positioning the Halal Food Industry: The Case of Malaysia. Nida Case Research Journal, 4(8), 157-174.

Park, M., \& Jamaludin, M. A. (2018). A Framework of Halal Industry Support System in non-Muslim Country: A Focus on South Korea. Journal of Halal Industry and Service, 1(1), 1-14.

Pratisti, C., \& Maryati, S. (2019). Halal Marketing and Financial Performance: 
Study in Cosmetic Companies in Indonesia Institute of Informatics and Business Darmajaya Institute of Informatics and Business Darmajaya. Kinerja, 23(1), 15-27.

Ratanamaneichat, C., \& Rakkarn, S. (2013). Quality Assurance Development of Halal Food Products for Export to Indonesia. Procedia - Social and Behavioral Sciences, 88(July), 134-141. https://doi.org/10.1016/j.sbspro.2013.0 8.488

Standard, D., \& Reuters, T. (2018). State of the Global Islamic Economy Report 2018/19. In Dubai International Financial Centre.

https://haladinar.io/hdn/doc/report20 18.pdf

Tieman, M., \& Darun, M. R. (2015). A Supply Chain Approach toward Halal. Journal of Halal Research, 1(1), 15-18.

Tri Ratnasari, R., Gunawan, S., Alif Rusmita, S., \& Prasetyo, A. (2019). Halal Food Certification to Improve the Competitiveness of East and Middle Business in Indonesia. KnE Social Sciences, 3(13), 1044. https://doi.org/10.18502/kss.v3i13.426 6

Waharini, F. M., \& Purwantini, A. H. (2018). Model Pengembangan Industri Halal Food di Indonesia Model Pengembangan Industri Halal Food di Indonesia. July. https://doi.org/10.18326/muqtasid.v9i1 $.1-13$ 
Journal of Digital Marketing And Halal Industry

Vol. 2, No. I (2020) 55-64 